\title{
Composting of cow manure and rice straw with cow urine and its influence on compost quality
}

\author{
Nghiên cứu ảnh hưởng của việc sử dụng nước tiểu bò lên quá trình ủ phân \\ compost tù phân bò và rơm \\ Research article
}

Nguyen Thanh Phong*, Nguyen Thi Ngoc Quynh

Department of Environmental Engineering, Faculty of Science and Engineering, Hoa Sen University, Ho Chi Minh city, Vietnam

\begin{abstract}
The aim of this study was to assess the effect of composting process of cow manure and rice straw with application of cow urine and to evaluate the quality of composting products. There were two treatment piles, in which one pile was applied with cow urine every week and another pile without urine application. Each pile was set up by one tone cow manure and $500 \mathrm{~kg}$ rice straw. The piles were half-covered by plastic foil to protect from rain and turned one a week. The composting duration lasted 8 weeks. The parameters such as temperature, $\mathrm{pH}, \mathrm{DM}$, density and nitrogen were monitored and observed during the 8 -week period. The results showed that there was a significant difference in temperature, compost quality and duration between two piles with and without cow urine application. The application of cow urine increased significant nitrogen and phosphorous content and shortened the composting process. This study recommends that cow urine should be applied for composting process of cow manure and rice straw in order to increase the quality of compost. The final product was in the range of matured compost level and can be used directly for agriculture crop.
\end{abstract}

\begin{abstract}
Mục tiêu của nghiên cứu nhằm đánh giá ảnh huởng đến chất luợng phân compost của việc bổ sung nuớc tiểu vào trong quá trình ủ phân tù nguyên liệu phân bò và rơm rạ. Thí nghiệm được thực hiện trên hai đống ủ phân, một đống ủ được bổ sung nước tiểu bò hàng tuần và một đống ủ không bổ sung nước tiểu bò nhu là một nghiệm thức đối chứng. Mỗi đống ủ được trộn 1 tấn phân bò và $500 \mathrm{~kg}$ rơm. Đống ủ phân được đậy kín một nửa phía trên nhằm ngăn cản ảnh huởng của muxa và được đảo trộn một lần mối tuần. Quá trình thí nghiệm được tiến hành trong 8 tuần. Các chỉ tiêu nhu nhiệt độ, $p H, D M$, mật độ và chất dinh duõng Nito và Phốt Pho được quan trắc trong thời gian ủ. Kết quả cho thấy có sụ khác biệt đáng kể giữa hai đống phân ủ đối với các chỉ tiêu nhu nhiệt độ, chất lượng phân compost và thời gian ủ. Đống ủ phân có bổ sung nuớc tiểu có hàm lượng Nitơ và Phốt pho cao hơn và thời gian ủ ngắn hơn. Kết quả nghiên cúu khuyến cáo nên bổ sung nước tiểu bò cho quá trình ủ phân compost nhằm tăng hàm luợng chất dinh duõng cho sản phẩm phân compost. Sản phẩm sau quá trình ủ đạt mức độ phân hũu cơ và có thể sủ dụng cho cây trồng.
\end{abstract}

Keywords: composting, cow manure, nitrogen, nutrient content, phosphorous, urine

\section{Introduction}

Cow manure and urine can provide nutrients for agriculture (Schmidt et. al., 2015; Beatriz et. al., 2017). The manure can be used as an input for biogas production but, if managed inappropriately, can also have a negative impact on the environment (Putria et. al., 2012). Cow urine contains a lot of valuable nutrients such as $\mathrm{N}$ and $\mathrm{P}$ (Sunita et. al., 2017; Nelson et. al., 2009). Previous study has found that cow urine contains $12.6 \mathrm{mg} \mathrm{L}^{-1} \mathrm{~N}, 97.8 \mathrm{mg}$ $\mathrm{L}^{-1}$ and 2.666mg L $\mathrm{m}^{-1} \mathrm{~K}$ (Nelson et. al., 2009).

Recycling nutrients from urine has many advantages: rather than diverting directly into canals and rivers as it is 
common practice in Vietnam, the valuable nutrients can be recovered by transforming into compost product. In this way, nutrients contained in urine can be used as a fertilizer in agriculture instead of causing environmental pollution such as eutrophication of lakes and rivers. According to Tiquia and Tam (2002), composting is a biological treatment that is cost-effective to treat different types of organic waste. It is a simple and environmental friendly technology for recycling agricultural residues and animal manure (Ahn et al., 2011). Also, farmers could spend less money when replacing mineral fertilizers with urine-based compost. The abundance of cow manure and rice straw can be converted to fertilizer throughout the process of composting (Tamura and Osada, 2006). Composting of cow manure and rice straw using urine as an addition to increase nutrients in the compost has not been well studied. Therefore, it is essential to study the effect on urine application during the composting process.

The objective of this study is to examine the application of urine in the composting process. To achieve the aim, two compost piles containing materials: cow manure and rice straw were set up in small farm, in which one pile was applied with cow urine every week and another pile without urine application.

\section{Materials and methods}

\subsection{Pile materials and set up}

The experiment was conducted in a small farm in Ben Tre province, from July to August in 2017. Cow manure, rice straw and cow urine were collected in the small farm. In this study, cow manure was used as the main material for composting together with rice straw. The chopped rice straw was soaked in the water for one day before the composting process. Composting was carried out in a shaded area.

Experimental piles initially had a triangle-shaped profile (height $1.0 \mathrm{~m}$; later on during the biological degradation processes, the profile changed to parabolic-shaped) and the composting process lasted 8 weeks. Compost aeration was ensured by manual mixing every week.
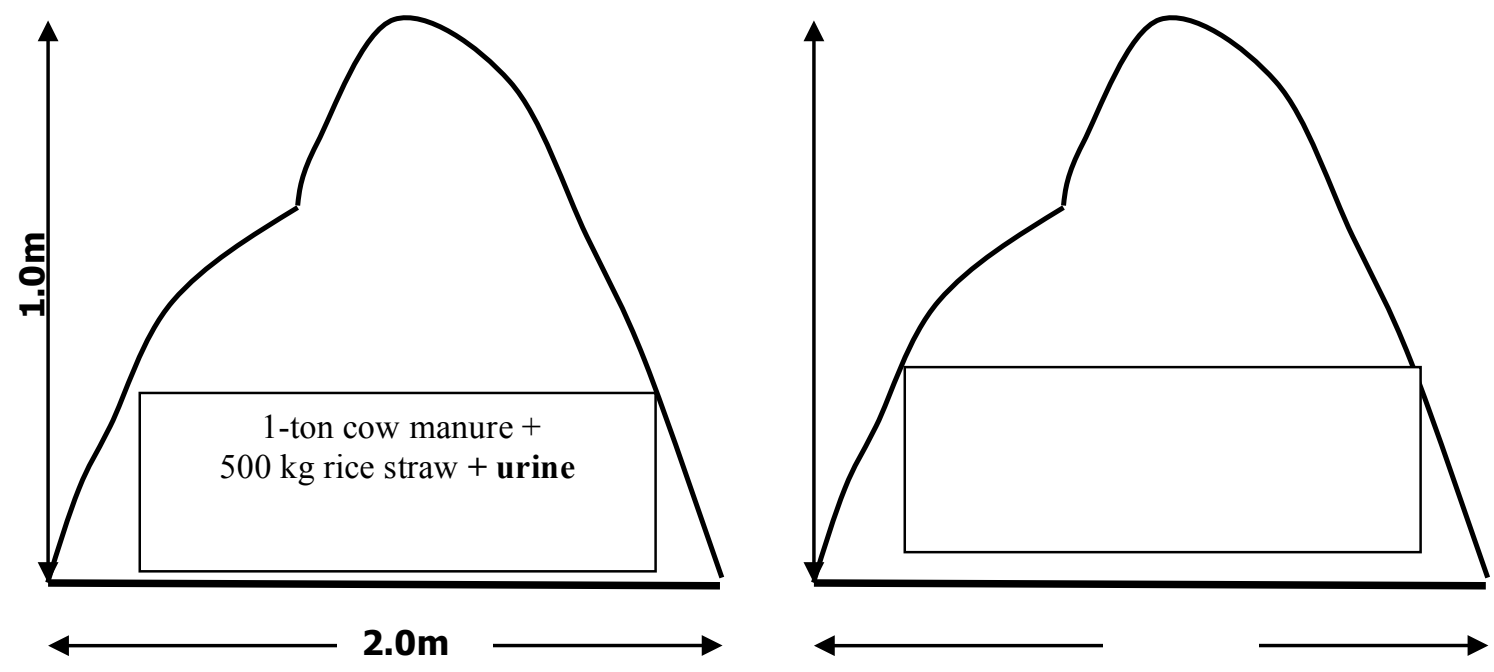

Figure 1. Schematic of experiment set up
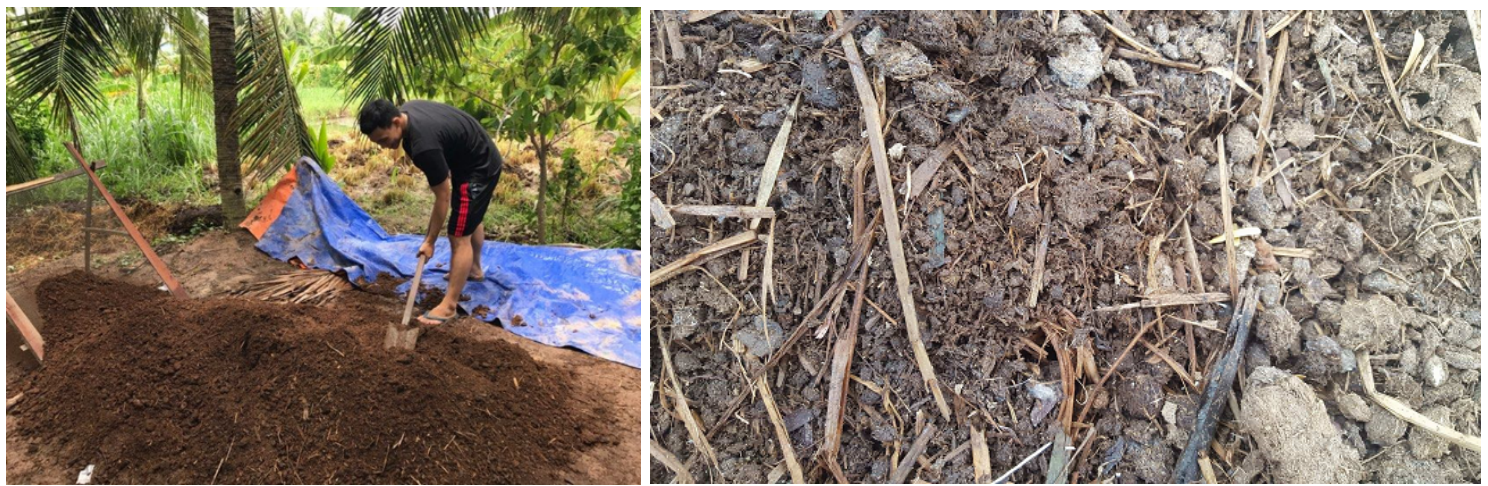

Figure 2. Left: Mixing the compost pile. Right: Mixture of cow manure, rice straw and urine 


\subsection{Experiment}

The basic method was to test the urine application on composting piles of cow manure and rice straw. In this experiment, there were two treatments compost piles with urine application (A) and without urine application (B). The mixtures used for all piles were arranged with the mass ratio as follows: 1-ton cow manure $+500 \mathrm{~kg}$ rice straw. Cow urine was collected and used within 24 hours. Two compost piles were set up as Figure 1. The experiment was conducted in the household conditions.

For piles with urine addition, fresh urine was added to the mixture every week (Figure 2). The moisture content was maintained at $50-60 \%$ by the addition of urine for pile $\mathrm{A}$ and water for pile $\mathrm{B}$ throughout the active composting period by frequent checking. The piles are half-covered by plastic foil to protect from evaporation and turned over once a week. The composting duration lasted 8 weeks. The parameters such as temperature, $\mathrm{pH}$, DM, nitrogen and phosphorous were observed during the composting duration. The temperature was measured weekly with a digital thermometer at 11 different depths.

Compost samples were taken from each treatment at 0,7 , $14,21,28,35,42,49$ and 56 days of the composting and were determined moisture and $\mathrm{pH}$ throughout the composting process. The samples taken from the piles were divided into two portions. Moisture content was determined using the gravimetric method. 100 grams of compost material was dried in an oven for $24 \mathrm{~h}$ at $105^{\circ} \mathrm{C}$. The samples were then allowed to cool at room temperature before the final weight was taken. The $\mathrm{pH}_{\mathrm{H} 2 \mathrm{O}}$ was determined using a digital electrode $\mathrm{pH}$ meter. Total nitrogen and phosphorous were determined at the end of the composting process using the TCVN 8557-2010 (2007) and TCVN 8563-2010 (2007) methods accordingly.

\section{Results and discussion}

\subsection{Temperature monitoring}

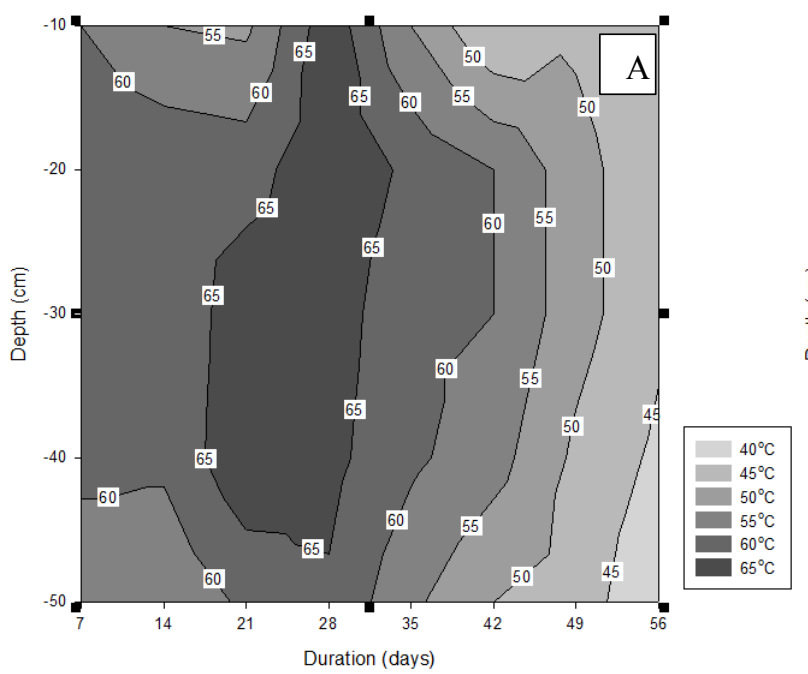

The temperature profiles of two different composting piles are shown in the Figure 3. The pile with urine application (A) shows an increase in temperature right after composting started. On day 7 , the temperature rose to $60^{\circ} \mathrm{C}$; whereas pile without urine application (B) was still $35^{\circ} \mathrm{C}$. The temperature in the pile $\mathrm{B}$ increased slowly to $60^{\circ} \mathrm{C}$ after 14 days. Even though no microbial test was done on the sample, it could be assumed that the compost treatment A (with urine application) had faster microbial activity compared to pile B based on the high temperature achieved.

The temperature pattern showed that there was a rapid progress from the initial mesophilic phase to the thermophilic phase for both piles. The results are in line with previous study results (Karolina and Mária, 2010; Jusoh et al., 2013; Hellmann et al. 1997; Osada et al., 2001). These authors found that temperatures in the compost pile reached highest after 2 weeks composting. The increase in temperature during the composting process was caused by the heat generated from the respiration and decomposition of organic substances by the population of microorganisms (Jusoh et al., 2013). All the composting treatments reached thermophilic temperature $\left(>60^{\circ} \mathrm{C}\right)$ after 14 days. The thermophilic phase lasted for 56 days for treatment A, whereas treatment B lasted for 42 days.

The results in the Figure 3 illustrated that the temperature gradually decreased afterwards and finally stabilized at lower than $50^{\circ} \mathrm{C}$ after 7 weeks.

From the top to the bottom of the piles, the low temperatures recorded were at -10 and $-50 \mathrm{~cm}$ for pile A and -10 and $-40 \mathrm{~cm}$ for pile B. The highest temperatures, which was $65^{\circ} \mathrm{C}$ at the day 21 for pile $\mathrm{A}$ and $60^{\circ} \mathrm{C}$ at the day 28 for pile B. After that, the temperature values declined to $40^{\circ} \mathrm{C}$ at the day 56 for both piles.

Figure 3. Change in temperature during composting processes. A: Compost pile with urine application, B: Compost pile without urine addition 


\subsection{Moisture monitoring}

The compost material at middle of pile A lost water quickly in the first week, due to the high temperature
(Figure 4). During this period, urine was added into the pile to maintain the moisture content (MC) at a suitable level for the microbe's activity.

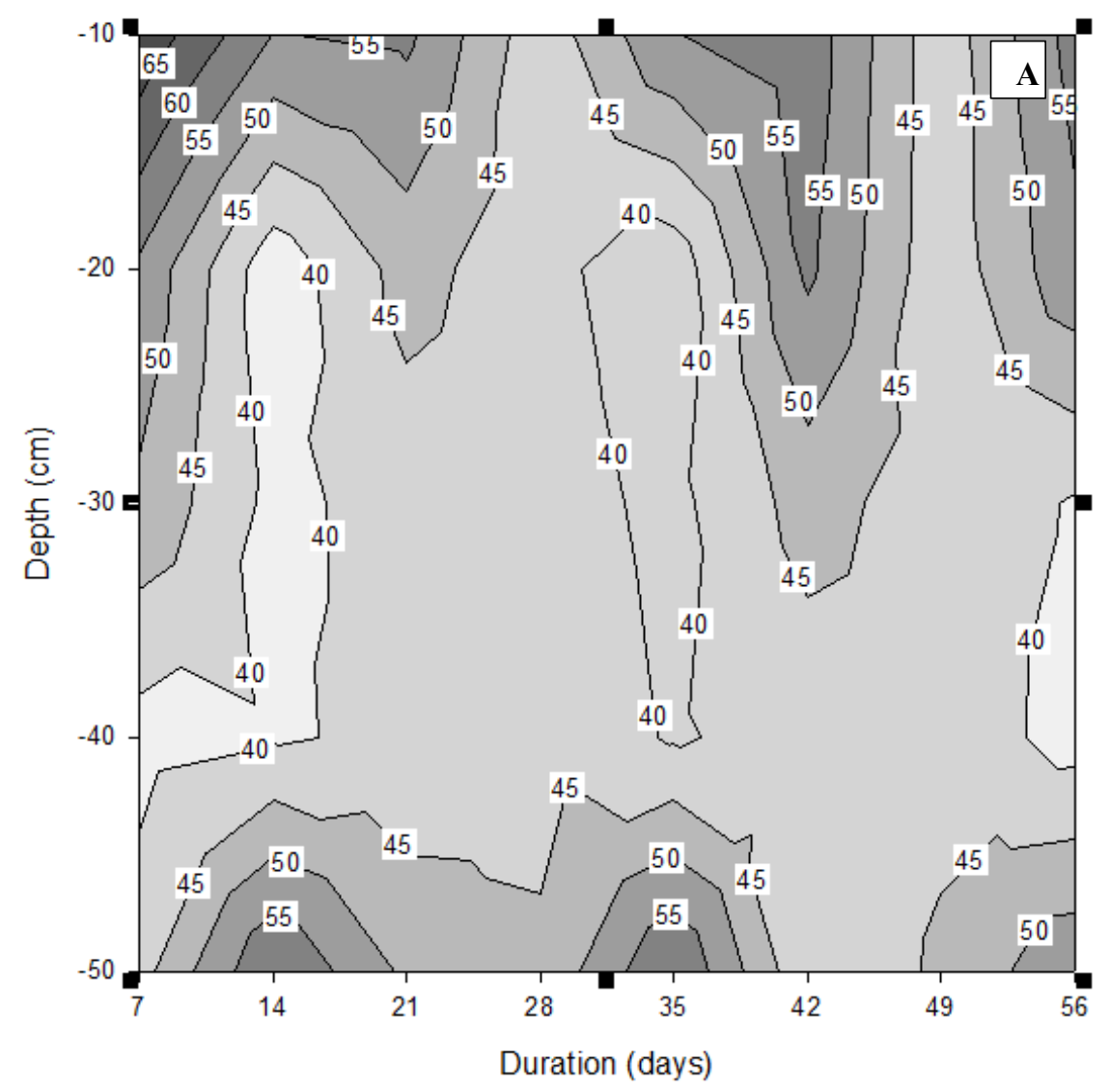

WH 35 (\%) WH $40(\%)$

WH $50(\%)$

WH $55(\%)$

WH $60(\%)$

WH $65(\%)$

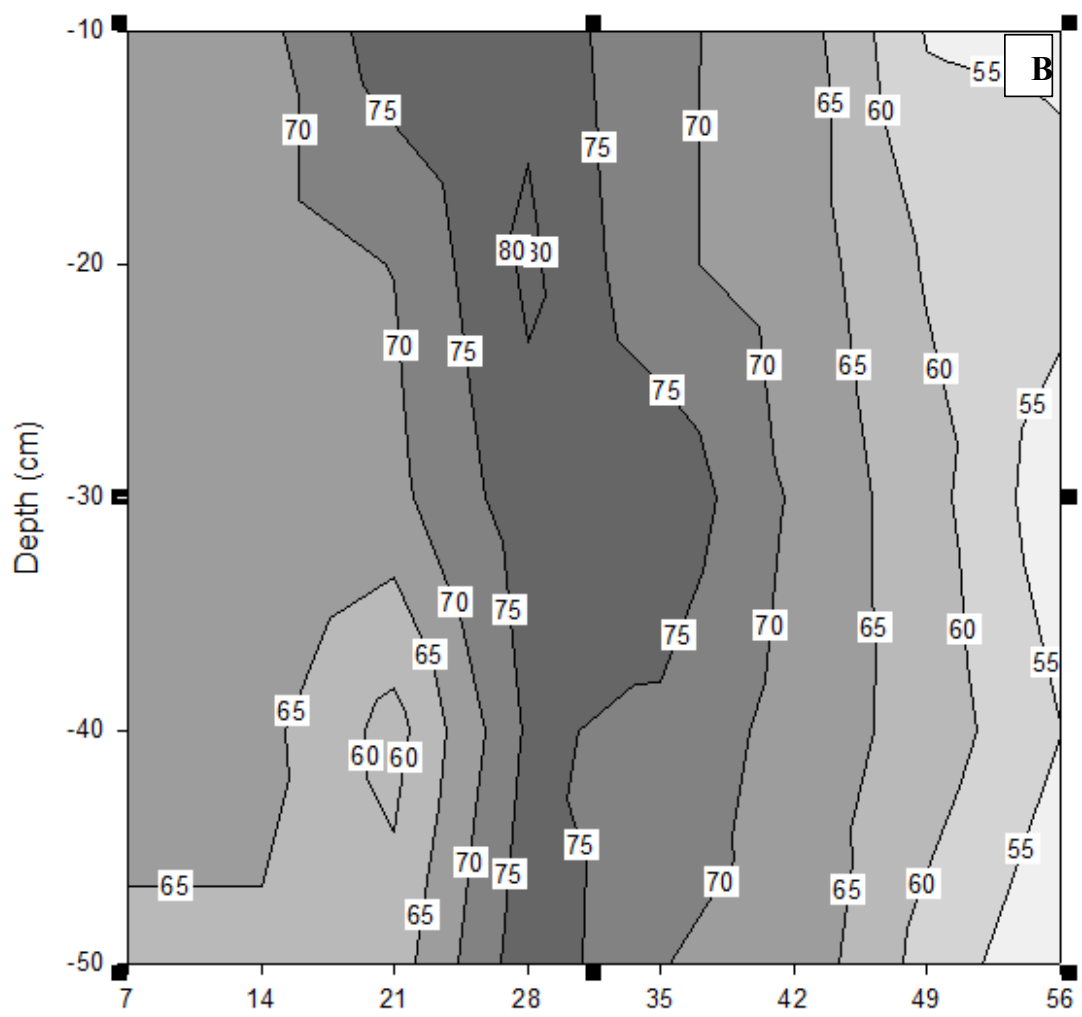

WH $35(\%)$

WH 40 (\%)

WH $50(\%)$

WH $55(\%)$

WH $60(\%)$

WH $65(\%)$

Duration (days)

Figure 4. Change in water holding (\%) during composting processes. A: Compost pile with urine application, B: Compost pile without urine application 
Generally, the MC decreased over process time in both compost piles, but decreased greater in pile A. The decrease of $\mathrm{MC}$ during composting course was in agreement with comparable data from other authors (Marco et al., 2010; Adani et al., 2000; Tao et al., 2011). Turning operations which were performed along the process should tend to decrease moisture contents. In addition, the increase of temperature in the compost pile also increased water evaporation. The moisture contents were higher on the surface and decreased with depth.

The decrease of MC from the $-10 \mathrm{~cm}$ to $-50 \mathrm{~cm}$ was due to biological activity that generated heat. Compost pile A showed lower MC than pile B. This could be explained by the fact that temperature in the pile A was higher than in the pile B. Higher temperature led to higher amount of water evaporation.

In the compost $\mathrm{A}$, the highest $\mathrm{MC}$ were $65 \%$ at $-10 \mathrm{~cm}$ (the temperature ranged from 50 to $55^{\circ} \mathrm{C}$ ) and the lowest was $40 \%$ at -30 to $-40 \mathrm{~cm}$ (the temperature was from 60 to $\left.65^{\circ} \mathrm{C}\right)$.

\section{4. pH monitoring}

The $\mathrm{pH}$ values of 2 compost piles during composting course are shown in the Figure 5. The $\mathrm{pH}$ recorded ranged from 6.6 to 7 for pile B and from 7.2 to 7.8 for pile A. The $\mathrm{pH}$ values for both treatments tended to increase in the first week. The results are in line with the finding of Sundberg and Jonsson (2008). The authors found that there was a rise in $\mathrm{pH}$ from the start of composting.

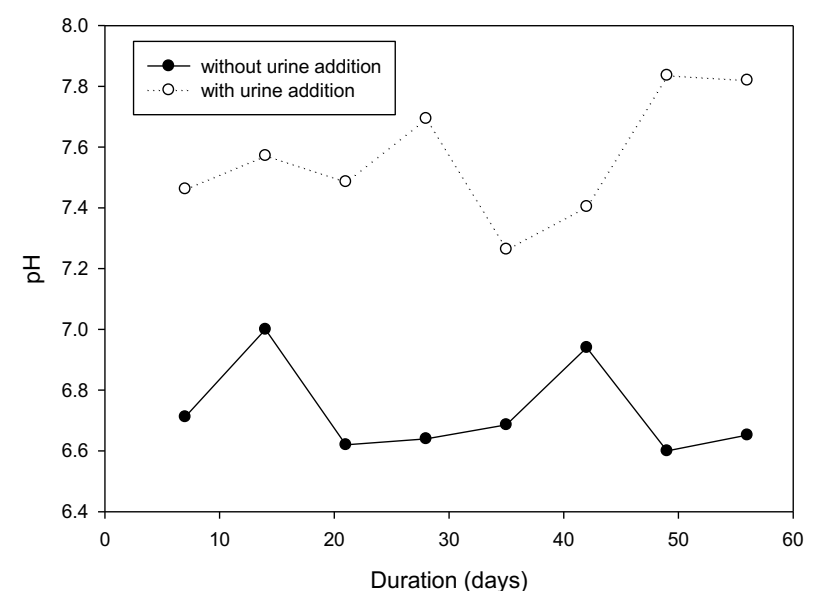

Figure 5. Change in $\mathrm{pH}$ of composting with and without urine application with days

The $\mathrm{pH}$ values at the end of the composting process was 7.8 for pile A and 6.7 for pile B. This $\mathrm{pH}$ values indicated a good quality compost. Previous study reported that $\mathrm{pH}$ of compost ranged from $6-8.5$ (Fogarty and Tuovinen, 1991), whereas Smars (2002) found that composting is inhibited at $\mathrm{pH}$ below 6 . Sundberg and Jonsson (2008) did an experiment on composting of biowaste, which indicated that $\mathrm{pH}$ is an important parameter to control composting processes. At higher $\mathrm{pH}$ condition, it could be faster decomposition in biowaste composting and result in a more stable compost product.

\subsection{Compost quality}

Two of the parameters often used to assess the quality of compost are Nitrogen $(\mathrm{N})$ and Phosphorous (P) contents. Figure 6 shows the total $\mathrm{N}$ and $\mathrm{P}$ in 2 compost piles. $\mathrm{N}$ content in the compost pile with urine addition was 1.5 times higher than that in the pile without urine addition. The total $\mathrm{N}$ value was $0.15 \%$ for treatment with urine and $0.1 \%$ for treatment without urine.

Similarly, it was observed that the P content in compost with urine addition was 2 times higher than compost without urine. The total $\mathrm{P}$ value was $0.42 \%$ for treatment with urine and $0.22 \%$ for treatment without urine. The results were slightly than that from other author, who found $\mathrm{P}$ content in compost ranged from 0.15 to $0.22 \%$ (Jusoh et al., 2013).

The high nutrients ( $\mathrm{N}$ and $\mathrm{P}$ ) in the compost pile A could be explained by high concentration of nutrient in urine, which was added in the compost pile.

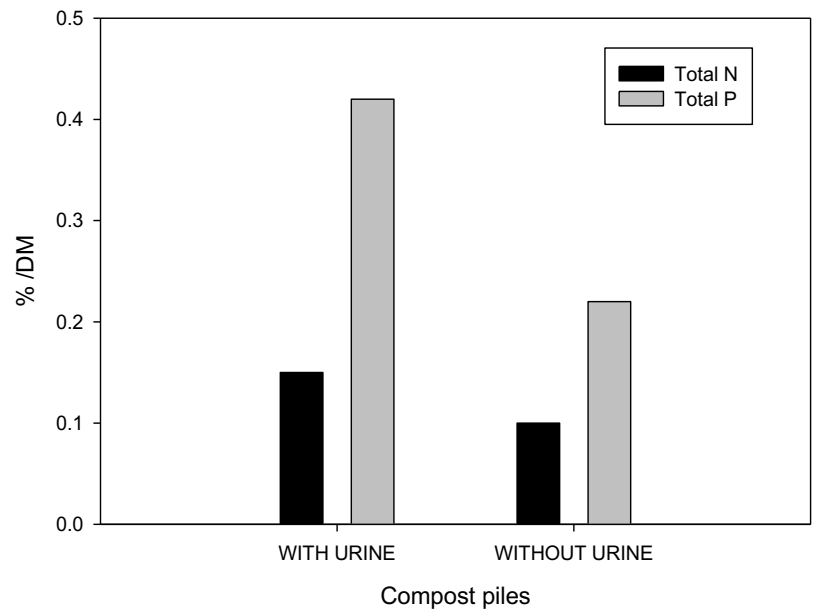

Figure 6. Total Nitrogen and Phosphorous in the compost products

\section{Conclusion}

Cow urine addition increased temperature and $\mathrm{pH}$ during composting process of cow manure and rice straw. The high temperatures showed that there was the decomposition of organic matter during the composting duration.

The application of urine could also shorten the composting duration.

There were differences between compost quality with urine and without urine addition. The application of urine increased $\mathrm{N}$ and $\mathrm{P}$ in the compost product compared to compost without urine.

Generally, based on the obtained results, it is possible to conclude that urine should be collected and added into the composting process of cow manure and rice straw. This implication could lead to increase nutrient content in the compost product and reduce nutrient loss and negative environmental impacts. 
Acknowledgement: The findings were funded by Hoa Sen University for the service learning project: "Nutrient recovery in small farms in Ben Tre province, proposal of solutions on sustainable use of cow urine". The authors also thank to the supports from Viet Nam Farmers' Union in Ba Tri town, Ben Tre province and Heifer.

\section{References}

[1] Adani, F., Scatigna, L., Genevini, P. (2000) Biostabilization of mechanically separated municipal solid waste fraction. Waste Manag. Res. 18 (5), 471-477.

[2] Ahn H.K., Mulbry W., White J.W., Kondrad S.L. (2011) Pile mixing increases greenhouse gas emissions during composting of dairy manure, Bioresource Technology 102, 2904-2909.

[3] Beatriz G. M., Jakob M., Lars S. J. (2017) Nitrogen turnover, crop use efficiency and soil fertility in a long-term field experiment amended with different qualities of urban and agricultural waste, Agriculture Ecosystems \& Environment 240:300-313.

[4] Fogarty A. and Tuovinen O. (1991) Microbiological degradation of pesticides in yard waste composting. Microbiol Rev, 55:225-233.

[5] Hellmann B., Zelles L., Palojarvi A., Bai Q. Y. (1997) Emission of climate-relevant trace gases and succession of microbial communities during openwindrow composting. Applied and Environmental Microbiology, 63(3): 1011-1018.

[6] Karolina M. and Mária K. (2010) Influence of compost covers on the efficiency of biowaste composting process, Journal of Waste Management, 30: 24692474.

[7] Jusoh M. L. C., Manaf L. A. and Latiff P. A. (2013) Composting of rice straw with effective microorganisms (EM) and its influence on compost quality, Iranian Journal of Environmental Health Sciences \& Engineering, 10:17.

[8] Marco B., Fernando A., Manuel S. G., Bernard M., Ana S. (2010) Composting kinetics in full-scale mechanical-biological treatment plants, Waste Management 30, 1908-1921.

[9] Nelson L. C de O., Mário P., Ricardo H. S., Paulo R. C., Pedro H. R. R. (2009) Soil and leaf fertilization of lettuce crop with cow urine, Hortic. Bras. vol.27 no.4 Brasília.
[10] Osada T, Sommer S G, Dahl P, Rom H B (2001) Gaseous emission and changes in nutrient composition during deep litter composting. Acta Agriculturae Scandinavica Section B-Soil and Plant Science, 51(3):137-142.

[11] Putria D. A., Saputrob R.R., and Budiyono (2012) Biogas Production from Cow Manure, Journal of Renewable Energy Development, (2) 2012:61-64.

[12] Smars, S. (2002) Influence of diff erent temperature and aeration regulation strategies on respiration in composting of organic household waste, Department of Agricultural Engineering, Swedish University of Agricultural Sciences: Doctoral thesis, Agraria 324, Uppsala, Sweden.

[13] Schmidt, H.P., Pandit, B.H., Martinsen, V., Cornelissen, G., Conte, P., Kammann, C.I. (2015) Fourfold increase in pumpkin yield in response to low-dosage root zone application of urine-enhanced biochar to a fertile tropical soil. Agri., 5: 723-741.

[14] Sunita C., Manish K., Seema P. S., Sodani S. K. (2017) Cow Urine: A Boon for Sustainable Agriculture, International Journal of Current Microbiology and Applied Sciences (2017) 6 (2): 1824 - 1829.

[15] Sundberg C. and Jonsson H. (2008) Higher pH and faster decomposition in biowaste composting by increased aeration, Journal of Waste Management 28, 518-526.

[16] Tamura T. and Osada T. (2006) Effect of moisture control in pile-type composting of dairy manure by adding wheat straw on greenhouse gas emission, International Congress Series 1293, ICS, 311 - 314.

[17] Tao J., Frank S., Guoxue L., Rui G. and Yuanqiu Z. (2011) Eff ect of $\mathrm{C} / \mathrm{N}$ ratio, aeration rate and moisture content on ammonia and greenhouse gas emission during the composting, Journal of Environmental Sciences, 23(10) 1754-1760.

[18] TCVN 8557-2010 (2007) Fertilizers - Method for determination of total nitrogen, Vietnamese Standards and Technical Regulations.

[19] TCVN 8563-2010 (2007) Fertilizers - Method for determination of total phosphorus, Vietnamese Standards and Technical Regulations.

[20] Tiquia S. M. and Tam N. F. Y. (2002) Characterization and composting of poultry litter forced-aeration piles. Process Biochem, 37:869-880. 